\title{
Editorial: GPER: Control and Functions
}

\author{
Yves Jacquot ${ }^{1 *}$, Marilena Kampa ${ }^{2}$ and Sarah H. Lindsey ${ }^{3}$ \\ ${ }^{1}$ CiTCOM, CNRS UMR 8038, INSERM U1268, Faculté de Pharmacie de Paris, Université de Paris, Paris, France, \\ ${ }^{2}$ Laboratory of Experimental Endocrinology, School of Medicine, University of Crete, Heraklion, Greece, ${ }^{3}$ Department of \\ Pharmacology, Tulane University, New Orleans, LA, United States
}

Keywords: G protein-coupled estrogen receptor, sexual dimorphism, central nervous system, heart tissue, signaling cascade, endocrine-disrupting chemicals, GPER turnover, modeling approaches

\section{Editorial on the Research Topic}

\section{GPER: Control and Functions}

Since the pioneering work of Elwood V. Jensen (1920-2012), which led to the discovery of estrogenbinding "substances" shortly afterwards called estrophilin, the concept of estrogen receptor (ER) has evolved considerably (1-3). Initial reports localized ERs in the nuclear compartment of cells of reproductive tissues after a translocation process from the cytoplasmic membrane to promote transcription $(4,5)$. Until the cloning of ER $\beta$ in 1996 in rat prostate and ovary (6), only one receptor, named ER $\alpha$, was known to bind the endogenous female hormone estradiol. In the following decades, at

\section{OPEN ACCESS}

Edited and reviewed by: Pierre De Meyts,

Université Catholique de Louvain, Belgium

${ }^{*}$ Correspondence: Yves Jacquot yves.jacquot@u-paris.fr

Specialty section:

This article was submitted to Molecular and Structural Endocrinology, a section of the journal Frontiers in Endocrinology

Received: 13 October 2021 Accepted: 22 October 2021 Published: 29 November 2021

Citation:

Jacquot $Y$, Kampa $M$ and Lindsey $S H$ (2021) Editorial: GPER:

Control and Functions.

Front. Endocrinol. 12:794344. doi: 10.3389/fendo.2021.794344 least three additional estrogen receptors were identified and cloned, i.e., GPER (7, 8), ERo46 (9), and ER $\alpha 36$ (10). ER $\alpha 46$ and 36 result from an alternative RNA splicing process of the gene ESR1 encoding $\mathrm{ER} \alpha(66 \mathrm{kDa})$, whereas GPER has its own transcript. The fact that estrogen receptors were discovered in the cytosol and cytoplasmic membrane of many different cell types, confirmed not only their ubiquitous character but also trafficking mechanisms in charge of the control of transcription. In the light of these observations, estrogen-mediated cellular signaling quickly became much more complex than initially claimed. In connection with these findings, two principal signaling processes were established, one initiated in the nucleus and the other at the cytoplasmic membrane.

Among estrogen receptors, GPER appears as the most atypical as it belongs to the family of class A (rhodopsin) G protein-coupled receptors (GPCRs) (11). Found in the cytoplasmic membrane, it can translocate to the membrane of the endoplasmic reticulum to exert specific functions (12) or to the trans-Golgi network for down-regulation (13). Based on what we know about the structure and functions of the classical estrogen receptor $E R \alpha$, this discovery was extremely surprising and stimulated conflicting debates about the role of GPER, i.e., whether it directly binds estradiol or functions as a protein partner of $\mathrm{ER} \alpha$, similar to coactivators. While the latter scenario is not definitively excluded, depending on the context, a network of observations supporting the direct interaction of estradiol with GPER prompted its renaming from GPR30 (Luo and Liu). Since GPER binds the female hormone estradiol, one "basic" question is: does GPER play a role in sexual dimorphism? The answer is far from definitive, with sex differences in GPER distribution between males and females observed in some studies but not others (14). GPER-mediated sexual dimorphism may lie in providing differences between males and females in the social and behavioral network, as explained by Dovey and Vasudevan. In specific regions of the central nervous system (hypothalamus and amygdala), sex differences in the distribution of GPER impact synaptic plasticity and as such, the perception of anxiety, social and object recognition, and spatial memory (Kumar and Foster). In this 
regard, changes in the interaction of females with their environment during the estrous cycle could be explained, at least in part, by GPER expression fluctuations in the central nervous system during this same period, as explained by Llorente et al. Functional crosstalk with classical estrogen receptors (principally ER $\alpha$ and ER36) and tyrosine kinase receptors (principally EGFR) has also been established (15). As such, it is not surprising that GPER interferes with kinase cascades and calcium flux, with consequences in the cardiovascular system, as explained by Tran, as well as on cell growth and neuronal transmission (Kumar and Foster). In this regard, it should be stressed that the submembrane part of GPER encompasses four $\mathrm{Ca}^{2+}$-calmodulin-binding sites, an observation that contributes to making this protein atypical (16). Such mechanisms could also play a role in glucose metabolism and obesity, opening new and exciting clinical opportunities.

As observed with the classical estrogen receptor ER $\alpha$, endocrine-disrupting chemicals such as bisphenols, dichlorodiphenyltrichloroethane (DDT), polychlorinated biphenyls (PCBs) and phytoestrogens (e.g., genistein) promote cell proliferation and migration through GPER, as reviewed by Périan and Vanacker. Such observations impose the development of a low-to-middle throughput method to detect endocrine disrupting agents acting through GPER. Such method is now available (Périan et al.). In this context, an impact of soy isoflavones on promoting glial cell migration through GPER has been evidenced (Ariyani et al.). Strikingly, tamoxifen, which is widely used to fight estrogen-dependent breast cancer by directly interfering with the estradiol-binding site of $\mathrm{ER} \alpha$, up-regulates

\section{REFERENCES}

1. Jensen EV, Suzuki T, Numata M, Smith S, De Sombre ER. Estrogen-Binding Substances of Target Tissues. Steroids (1969) 13:417-27. doi: 10.1016/0039$128 x(69) 90053-1$

2. De Sombre ER, Puca GA, Jensen EV. Purification of an Estrophilic Protein From Calf Uterus. Proc Natl Acad Sci U S A (1969) 64:148-54. doi: 10.1073/ pnas.64.1.148

3. Greene GL, Closs LE, Fleming H, De Sombre ER, Jensen EV. Antibodies to Estrogen Receptor: Immunochemical Similarity of Estrophilin From Various Mammalian Species. Proc Natl Acad Sci U S A (1977) 74:3681-5. doi: 10.1073/ pnas.74.9.3681

4. Ruh TS, Ruh MF. The Effect of Antiestrogens on the Nuclear Binding of the Estrogen Receptor. Steroids (1974) 24:209-24. doi: 10.1016/0039-128x(74) 90104-4

5. Tsay SY, Tsai MJ, Schwartz R, Kalimi M, Clarck JH, O’Malley BW. Effects of Estrogen on Gene Expression in Chick Oviduct: Nuclear Receptor Levels and Initiation of Transcription. Proc Natl Acad Sci U S A (1975) 72:4228-32. doi: $10.1073 /$ pnas.72.11.4228

6. Kuiper GG, Enmark E, Pelto-Huikko M, Nilsson S, Gustafsson JA. Cloning of a Novel Receptor Expressed in Rat Prostate and Ovary. Proc Natl Acad Sci U S A (1996) 12:5925-30. doi: 10.1073/pnas.93.12.5925

7. Owman C, Blay P, Nilsson C, Lolait SJ. Cloning of Human cDNA Encoding a Novel Heptahelix Receptor Express in Burkitt's Lymphoma and Widely Distributed in Brain and Peripheral Tissues. Biochem Biophys Res Commun (1996) 228:285-92. doi: 10.1006/bbrc.1996.1654

8. Carmeci C, Thompson DA, Ring HZ, Francke U, Weigel RJ. Identification of a Gene (GPR30) With Homology to the G-Protein-Coupled Receptor
GPER and enhances cell proliferation, an observation that could explain, at least in part, tamoxifen resistance, as highlighted by Molina et al.

Hence, GPER appears not only as a key pleiotropic actor of mammalian hormone homeostasis but also as a promising target for the modulation of related physiological and pathological actions. However, the lack of crystal structure for GPER remains an obstacle to the development of modulators. Computational (virtual) approaches consisting of multiple protein sequence alignment combined with molecular docking of compound libraries have been proposed to identify new potential modulators or model explaining the mode of binding of active molecules (Grande et al.).

In this Research Topic celebrating 25 years since the discovery of GPER, many aspects of the functional role of GPER will be discussed.

\section{AUTHOR CONTRIBUTIONS}

All authors have contributed to the article and have approved the submitted version.

\section{FUNDING}

This work was supported by National Institutes of Health grant number HL133619 (SHL) and by the German Academic Exchange Service (DAAD project-ID: 57515112 (MK).
Superfamily Associated With Estrogen Receptor Expression in Breast Cancer. Genomics (1997) 45:607-17. doi: 10.1006/geno.1997.4972

9. Flouriot G, Brand H, Denger S, Métivier R, Kos M, Reid G, et al. Identification of a New Isoform of the Human Estrogen Receptor-Alpha ( $h E R \alpha)$ That is Encoded by Distinct Transcripts and That Is Able to Repress hER- $\alpha$. EMBO J (2000) 19:4688-700. doi: 10.1093/emboj/19.17.4688

10. Wang ZY, Zhang XT, Shen P, Loggie BW, Chang YC, Deuel TF. Identification, Cloning, and Expression of Human Estrogen Receptor- $\alpha 36$, a Novel Variant of Human Estrogen Receptor - $\alpha 66$. Biochem Biophys Res Commun (2005) 336:1023-7. doi: 10.1016/j.bbrc.2005.08.226

11. Prossnitz ER, Arterburn JB. International Union of Basic and Classical Pharmacology. XCVII. G Protein-Coupled Estrogen Receptor and its Pharmacologic Modulators. Pharmacol Rev (2015) 67:505-40. doi: 10.1124/pr.114.009712

12. Revankar CM, Cimino DF, Sklar LA, Arterburn JB, Prossnitz ER. A Transmembrane Intracellular Estrogen Receptor Mediates Rapid Cell Signaling. Science (2005) 307:1625-30. doi: 10.1126/science.1106943

13. Cheng SB, Quinn JA, Graeber CT, Filardo EJ. Down-Regulation of the GProtein-Coupled Estrogen Receptor, GPER, From the Cell Surface Occurs via Trans-Golgi-Proteasome Pathway. J Biol Chem (2011) 286:22441. doi: 10.1074/jbc.M111.224071

14. Hutson DD, Gurrala R, Ogola BO, Zimmerman MA, Mostany R, Satou R, et al. Estrogen Receptor Profiles Across Tissues From Male and Female Rattus Norvegicus. Biol Sex Differ (2019) 10:4. doi: 10.1186/s13293-019-0219-9

15. Pelekanou V, Kampa M, Kiagiadaki F, Deli A, Theodoropoulos P, Agrogiannis G, et al. Estrogen Anti-Inflammatory Activity on Human Monocytes is Mediated Through Crosstalk Between Estrogen Receptor ER $\alpha 36$ and GPR30/GPER1. J Leukoc Biol (2016) 99:333-47. doi: 10.1189/jlb.3A0914$430 \mathrm{RR}$ 
16. Tran QK, VerMeer M. Biosensor-Based Approach Identifies Four Distinct Calmodulin-Binding Domains in the G Protein-Coupled Estrogen Receptor 1. PLoS One (2014) 9:e89669. doi: 10.1371/journal.pone.0089669

Conflict of Interest: The authors declare that the research was conducted in the absence of any commercial or financial relationships that could be construed as a potential conflict of interest.

Publisher's Note: All claims expressed in this article are solely those of the authors and do not necessarily represent those of their affiliated organizations, or those of the publisher, the editors and the reviewers. Any product that may be evaluated in this article, or claim that may be made by its manufacturer, is not guaranteed or endorsed by the publisher.

Copyright (c) 2021 Jacquot, Kampa and Lindsey. This is an open-access article distributed under the terms of the Creative Commons Attribution License (CC BY). The use, distribution or reproduction in other forums is permitted, provided the original author(s) and the copyright owner(s) are credited and that the original publication in this journal is cited, in accordance with accepted academic practice. No use, distribution or reproduction is permitted which does not comply with these terms. 